\title{
Geoheritage in Europe and its conservation
}

This note is to bring to your attention a new publication from ProGEO, the European Association for Conservation of the Geological Heritage - an affiliated body of IUGS. This volume, Geoheritage in Europe, has just been published. Details can be found on the ProGEO website at http:// www.progeo.se/.

The volume outlines some of the basic principles in assessing and protecting geosites. It reveals the need to introduce more focussed laws for geoconservation in numerous countries, and to put more Earth scientists into governmental conservation bodies. Even when there is a responsible conservation agency in a country, Earth scientists are seldom employed, and rarely in decision-making jobs. Another issue to be addressed is that geological knowledge (in universities, geological surveys, or societies) is often divorced from the expertise (and power) in conservation.

Geologists and geographers were at the forefront in nurturing a juvenile nature conservation movement, promoting the preservation of the first national parks and natural monuments. However, today in conservation, globally, geology has become a poor relation.

Too often geology is reduced by the media to the obvious, the visual (minus the science) - volcanoes, dinosaurs, big structures - a Great Canyon syndrome. And it is often only used as a backdrop for biotic nature. But the key stages of the evolution of the Earth (organic and inorganic), and the fascinating science, are as much essential heritage as plants and animals. The natural heritage of any country includes its key geological elements - many key geosites, as well as landscapes profoundly shaped and defined by their geology. Fossils, rocks and minerals, and geological processes, are certainly natural heritage, something to be conserved for future generations.

The purpose of Geoheritage in Europe is to define the state of the art in geoconservation and to reveal the international differences, problems, challenges, and some successes. However, in some countries in Europe, and many outside, there is no statute or even no official/governmental awareness of the existence of geology, let alone of scientific heritage.

It must be said that everywhere geological heritage is under-valued and threatened, even in countries that have some relevant geoheritage legislation. Practice is so variable between countries: in one a scientifically unique site might be being quarried away or filled with waste, or a coastal cliff site be obliterated by hotel development; in another valid geological research is obstructed by oppressive bureaucratic (conservation) regulations; while in a third at some sites commercial dealers are busy carting off every fossil they can for sale - leaving little behind for scientific pursuits or wider educational use. In recent times, we have seen the famous Pikermian mammalian fossil site in Greece threatened and one of the best $\mathrm{J} / \mathrm{K}$ boundary sites in Ukraine destroyed.The threats to geological sites are essentially the same in all countries, what differs is the ability or willingness of state agencies to recognise and protect our shared geoscience heritage.

There has been the recent development of Geoparks, in which ProGEO took a founding role. Essential though it is to promote geology to a wider public, it has taken some minds off the ever-present issue - the survival of national/international geoheritage in the form of sites and areas that are often more difficult to popularise. If each country lacks an inventory of its geoscience heritage, it cannot work out its priorities for site protection, or join the fight for resources. And it is necessary to derive such priorities, for all localities cannot be protected in societies where the competition for resources is always acute.

Globally, a minority of countries do see geoconservation as an essential activity. However, in the world as whole, many states make no official recognition that geosites are cultural and scientific goods of national (/ international) importance (and worth protecting). For that reason, Europe has been something of a beacon for other parts of the world, and ProGEO its focus.

Geoconservation is about geosites, large and small, that is, their "protection for use". Other aims are subsidiary to this one defining aim. Knowledge and respect of the Earth's history can only be generated at critical field sites, and our science depends on such areas. No sites, no science - or education or training. As our science is a valued part of our culture, one hopes, their importance cannot be disputed. Once each country is sure that it has adequately protected its top sites, then, and only then, will it be time to think of other things.

This volume, ProGEO, will raise awareness of geoheritage under threat and demonstrate examples of good practice. It aims to bring to the attention of all Earth scientists the need to continually put geoheritage protection on the political and social agenda.

\section{W.A.P. Wimbledon \\ Dept. of Earth Sciences, \\ University of Bristol, $U K$}

